\title{
Behavioral and neuropharmacological evidence that serotonin crosses the blood-brain barrier in Coturnix japonica (Galliformes; Aves)
}

\author{
Polo, PA., Reis, RO., Cedraz-Mercez, PL., Cavalcante-Lima, HR., \\ Olivares, EL., Medeiros, MA., Côrtes, WS. and Reis, LC.* \\ Departamento de Ciências Fisiológicas, Instituto de Biologia, UFRuralRJ, CEP 23890-000, Seropédica, RJ, Brazil \\ *e-mail: 1creis@ufrrj.br
}

Received June 27, 2005 - Accepted August 25, 2005 - Distributed February 28, 2007

(With 3 figures)

\begin{abstract}
This study was carried out aiming to reach behavioral and neuropharmacological evidence of the permeability of the blood-brain barrier (BBB) to serotonin systemically administered in quails. Serotonin injected by a parenteral route (250-1000 $\mu \mathrm{g} . \mathrm{kg}^{-1}, s c$ ) elicited a sequence of behavioral events concerned with a sleeping-like state. Sleeping-like behaviors began with feather bristling, rapid oral movements, blinking and finally crouching and closure of the eyes. Previous administration of 5-HT2C antagonist, LY53857 (3 mg.kg-1,$s c)$ reduced the episodes of feather bristling and rapid oral movements significantly but without altering the frequency of blinking and closure of the eyes. Treatment with the 5-HT2A/2C antagonist, ketanserin $\left(3 \mathrm{mg} \cdot \mathrm{kg}^{-1}, s c\right)$ did not affect any of the responses evoked by the serotonin. Quipazine $\left(5 \mathrm{mg} \cdot \mathrm{kg}^{-1}, s c\right)$ a $5-\mathrm{HT} 2 \mathrm{~A} / 2 \mathrm{C} / 3$ agonist induced intense hypomotility, long periods of yawning-like and sleeping-like states. Previous ketanserin suppressed gaping responses and reduced hypomotility, rapid oral movements and bristling but was ineffective for remaining responses induced by quipazine. Results showed that unlike mammals, serotonin permeates the BBB and activates hypnogenic mechanisms in quails. Studies using serotoninergic agonist and antagonists have disclosed that among the actions of the serotonin, feather bristling, rapid oral movements and yawning-like state originated from activation of 5-HT2 receptors while blinking and closure of the eyes possibly require other subtypes of receptors.
\end{abstract}

Keywords: serotonin, blood brain barrier, hypnogenic action, sleep, yawning, quails.

\section{Evidências comportamentais e neurofarmacológicas de que a serotonina atravessa a barreira hematoencefálica em Coturnix japonica (Galliformes; Aves)}

\begin{abstract}
Resumo
Este estudo foi desenvolvido objetivando ampliar as evidências comportamentais e neurofarmacológicas da permeabilidade da barreira hematoencefálica (BHE) à serotonina administrada sistemicamente em codornas. A serotonina injetada por via parenteral $\left(250-1000 \mu \mathrm{g} . \mathrm{kg}^{-1}, s c\right)$ produziu uma seqüência de eventos relacionados com um estado semelhante ao sono. Comportamentos semelhantes ao sono começaram com o eriçamento das penas, movimentos orais rápidos, piscadelas e finalmente agachamento e fechamento dos olhos. A administração prévia do antagonista do receptor 5-HT2C, LY53857 (3 mg.kg $\left.{ }^{-1}, s c\right)$ reduziu significativamente os episódios de eriçamento das penas e movimentos orais rápidos, mas não alterou a frequiência de piscadelas e fechamento dos olhos. Tratamento com o antagonista do receptor 5-HT2A/ $2 \mathrm{C}$, quetanserina $\left(3 \mathrm{mg} \cdot \mathrm{kg}^{-1}, s c\right)$ não afetou nenhuma das respostas evocadas pela serotonina. A quipazina $\left(5 \mathrm{mg} \cdot \mathrm{kg}^{-1}, s c\right)$, um agonista dos receptores 5-HT2A/2C/3, induziu intensa hipomotilidade e longos períodos de comportamentos semelhantes ao bocejo e ao sono. $\mathrm{O}$ tratamento prévio com quetanserina suprimiu as reações de bocejo e reduziu a hipomotilidade, os movimentos orais rápidos e as piscadelas, mas foi sem efeito para as demais respostas induzidas pela quipazina. Os resultados mostraram que, diferentemente dos mamíferos, a serotonina atravessa a BHE e ativa mecanismos hipnogênicos em codornas. Estudos com agonistas serotoninérgicos e antagonistas revelaram que, entre as ações da serotonina, o eriçamento das penas, os movimentos orais rápidos e o comportamento semelhante ao bocejo foram originados pela ativação de receptores 5-HT2, enquanto o piscar e o fechamento dos olhos possivelmente requereu outros subtipos de receptores.
\end{abstract}

Palavras-chave: serotonina, barreira hematoencefálica, ação hipnogênica, sono, bocejo, codornas. 


\section{Introduction}

Serotonin (5-HT) synthesis is fulfilled from its precursor, the amino acid, L-tryptophan. The first step of 5-HT synthesis requires the participation of the L-5-hydroxytryptophan hydroxylase, enzyme responsible for the formation of the L-5-hydroxytryptophan (Tyce, 1990; Boadle-Biber, 1993; Cooper et al., 1996).

After this, L-5-hydroxytryptophan is converted into 5-hydroxytryptamine (5-HT, serotonin) by the action of the L-amino acid aromatic decarboxilase (Tyce, 1990; Boadle-Biber, 1993; Cooper et al., 1996). In spite of many studies having been carried out on the brain 5-HT, a little less than $2 \%$ of the indoleamine is produced in the central nervous system relative to the whole organism (Cooper et al., 1996). The remaining 5-HT produced by the body arises from the gastrointestinal tract, mast cells, etc. Neuronal 5-HT can leak into the systemic circulation however it only permeates poorly the blood brain barrier (BBB) towards the brain in mammals (Cooper et al., 1996). Nevertheless, there is no study concerning this property in birds and its relationship with neuropharmacological and behavioral analysis.

Recently, the existence of an extraneuronal organic cation transporter subtype3 (OCT3) in rat brains was demonstrated which it recognizes 5-HT. An expression of this protein is regulated by a family of genes related to transporters of cations responsible for transporting various organic cations (Wu et al., 1998; Schmitt et al., 2003). However, this transport system is responsible for the clearance of this amine in the brain for metabolic inactivation and detoxification. Therefore, it is believed that the brain defends itself from the 5-HT excess (and from other amines) that escapes the synaptic cleft, as well as modulating its afflux through BBB.

Considering these observations, we aimed to investigate the evidence of the permeability of BBB to 5-HT in quails. Two investigation possibilities were undertaken: Firstly, 5-HT was administered by sc route in quails to evaluate behavioral reactions. Previous studies of our laboratory showed evidence of the central action of 5-HT systemically injected in the evaluation of its effect (and of their precursors) in the feeding behavior of quails (Reis et al., 2005). In such study, our group showed for the first time, a hypnogenic action induced by systemic serotonin. Obviously, this response is dependent on activating neural circuitry located inside the BBB. As that maneuver generated other behavioral reactions (especially hypnogenic responses), in the present study we examined the influence of previous administration of 5-HT2 antagonists on the responses induced by the 5-HT and 5-HT2A/2C agonists.

\section{Material and Methods}

\subsection{Animals used and experimental procedures}

Male quails (Coturnix japonica) weighing 130-175 g (3 to 4 months old) were used. Birds were housed in in- dividual cages under light: dark cycle control (lights on at 7 hours and lights off at 19 hours) and were offered $\mathrm{ad}$ libitum of water and food. Three series of studies were undertaken. Firstly, 5-HT was administered in the doses of zero, 250, 500 and 1,000 $\mu \mathrm{g} \cdot \mathrm{kg}^{-1}, s c(\mathrm{~N}=9$ for each group). In a second series, isotonic saline $(0.1 \mathrm{~mL} / 100 \mathrm{~g})$ or the serotoninergic antagonists of 5-HT2C, LY53857 and $5-\mathrm{HT} 2 \mathrm{~A} / 2 \mathrm{C}$ receptors, ketanserin $\left(3 \mathrm{mg} \cdot \mathrm{kg}^{-1}, \mathrm{sc}\right.$, for both drugs) were administered 30 minutes before saline or 5-HT $\left(500 \mu \mathrm{g} \cdot \mathrm{kg}^{-1}, s c\right)(\mathrm{N}=7$ for each group). In a third condition, saline or the serotoninergic antagonist, ketanserin $\left(3 \mathrm{mg} \cdot \mathrm{kg}^{-1}, \mathrm{sc}\right)$ was administered 30 minutes before the serotoninergic $5-\mathrm{HT} 3 / 2 \mathrm{~A} / 2 \mathrm{C}$ agonist, quipazine $\left(5 \mathrm{mg} \cdot \mathrm{kg}^{-1}, s c\right)$. Groups saline + saline, saline + quipazine and ketanserin + quipazine were constituted by 7,10 and 7 birds, respectively.

\subsection{Drugs}

The following drugs were used: serotonin (3-[aminoethyl]-5-hydroxyindole, creatinine sulfate complex), quipazine (2-[piperazinyl]quinoline, maleate salt), ketanserin (3[2-\{4-[4-fluorobenzoyl]-1piperidinyl \}ethyl]-2,4[1H.3H]-quinazolinedione, tartrate salt) were purchased from Sigma, St. Louis, U.S.A. and LY53857 (6-methyl-1-[1-methylethyl] ergoline-carboxylic acid was acquired from the Eli Lilly Company, Indianapolis, U.S.A.

\subsection{Behavioral analysis}

Behavioral observations were made during $30 \mathrm{~min}$ utes immediately after 5-HT or quipazine administration. The following behavioral responses were observed: feather bristling, rapid oral movements, crouching, blinking and closure of the eyes. These reactions were typical of the sleepiness phase and they forego the period of sleeping-like behavior in which the birds persisted with closed eyes.

\subsection{Statistical analysis}

Data of frequencies of feather bristling, rapid oral movements and blinking were analyzed by one-way ANOVA and Neuman-Keuls analysis as a post test. A two-tailed unpaired t test was used to compare between means of two groups of behaviors. Data were set significant when $\mathrm{p} \leq 0.05$.

\section{Results}

5-HT systemically injected stimulated the development of the hypnogenic state. Firstly, birds displayed rapid oral movements alternated by bristling and shaking of wings and were followed by episodes of blinking and closure of the eyes. A phase of rapid oral movement was preceded by a short period of gaping, a characteristic pattern of the yawning. During the sleeping-like state phase, the birds persistently stooped down for periods of 2-20 minutes.

With a dose of $250 \mu \mathrm{g} \cdot \mathrm{kg}^{-1}$, birds presented bristling, gaping, rapid oral movements, blinking and rarely 
they stooped or slept. With a dose of $500 \mu \mathrm{g} \cdot \mathrm{kg}^{-1}$, birds increased the frequency of bristling, rapid oral movements, blinking, and $50 \%$ of them continued stooping and with closed eyelids for 2-8 minutes. At a dose of $1,000 \mu \mathrm{g} \cdot \mathrm{kg}^{-1}$, the birds expressed all of the preparation stages for sleep, but at a lower frequency than in birds treated with smaller doses. However, $100 \%$ of them slept earlier and they persisted with closed eyes for a period of 5-20 minutes.

Treatment with the antagonist 5-HT2C, LY53857, $3 \mathrm{mg} \cdot \mathrm{kg}^{-1}$, reduced significantly the frequencies of bristling and rapid oral movements induced by 5 -HT, $500 \mu \mathrm{g} \cdot \mathrm{kg}^{-1}(\mathrm{p}<0.05)$ but without affecting the episodes of blinking and closure of eyes (Figure 1). In this condition, the short episodes of gape that were expressed before rapid oral movements were abolished. On the other hand, the 5-HT2A/2C antagonist, ketanserin, $3 \mathrm{mg} \cdot \mathrm{kg}^{-1}$, was ineffective for all the parameters analyzed (Figure 2). Treatment with 5-HT3/2A/2C agonist, quipazine, $5 \mathrm{mg} \cdot \mathrm{kg}^{-1}$, induced hypomotility in all the birds during 15-28 minutes with a latency of 0.5-3 minutes. A sleeplike state was manifested during the observation period in which the birds remained with their mouth open for a long time. Episodes of cloacal movements and closure of eyes were frequent throughout the observation. Similarly to 5-HT, quipazine caused an increase in the frequencies of bristling, rapid oral movements and blinking (Figure 3). Previous treatment with ketanserin reduced the rapid oral movements and bristling frequencies significantly, but was ineffective for the blinking response $(\mathrm{P}<0.05)$ (Figure 3). In addition, ketanserin suppressed the gaping response and did not change hypomotility and cloacal movements. Table 1 depicts the incidence of other patterns of behaviors shown throughout the sleeping-like

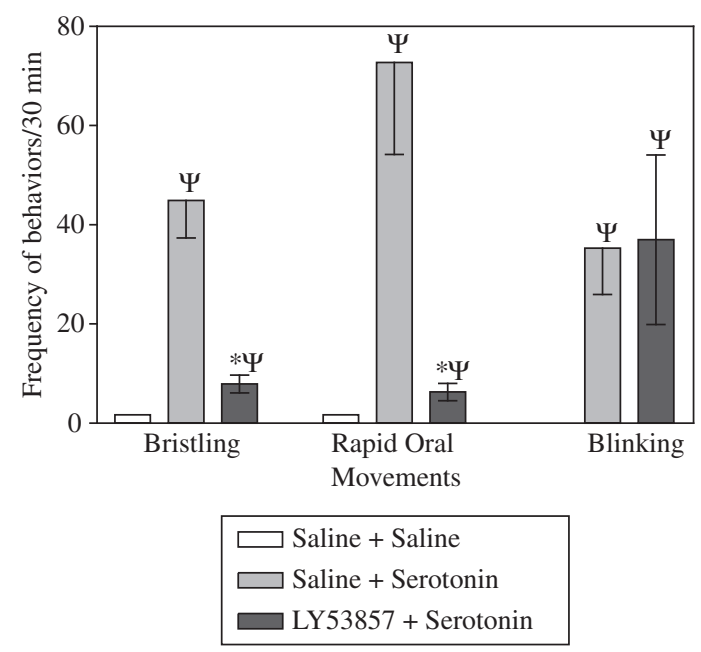

Figure 1. Frequency of behaviors associated to sleeping-like reactions induced by serotonin and after previous 5-HT2C antagonist, LY53857 treatment in quails. Data are reported as mean \pm SEM. ${ }^{*} \mathrm{p}<0.05$ compared to saline + serotonin group. ${ }^{\psi} \mathrm{p}<0.05$ compared to saline + saline group. state induced by 5-HT and quipazine comparatively to its combinations with antagonists.

\section{Discussion}

It has been evidenced that amines, particularly 5-HT, permeate poorly the BBB in mammals (Cooper et al., 1996). On the contrary, brains of mammals have developed defense mechanisms against the excessive extra-cellular concentration of 5-HT (Wu et al., 1998; Schmitt et al., 2003).

In a previous study, we demonstrated for the first time that 5-HT administered peripherally permeates the BBB in quails (Reis et al., 2005). Behavioral and neuropharmacological evidence of this response was investigated in the present study. The sequence of behavioral

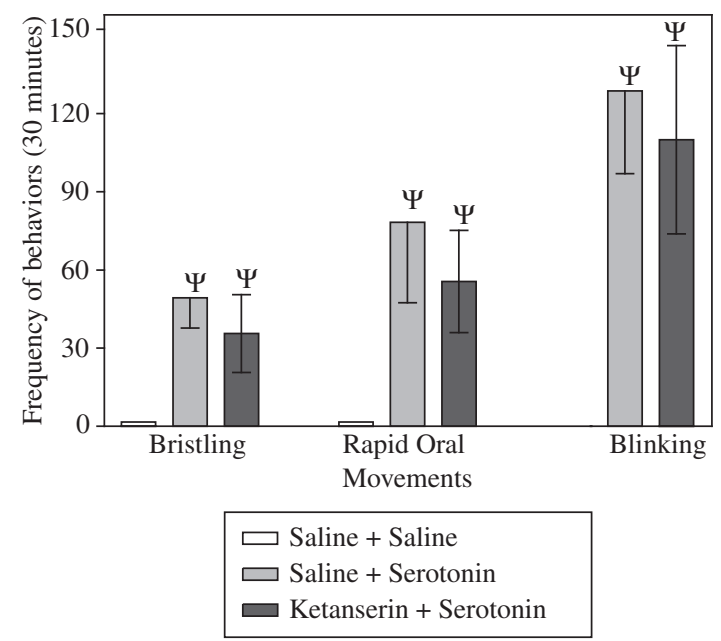

Figure 2. Frequency of behaviors associated to sleeping-like reactions induced by serotonin and after previous 5-HT2A/ $2 \mathrm{C}$ antagonist, ketanserin treatment. Data are reported as mean \pm SEM. ${ }^{\psi} \mathrm{p}<0.05$ compared to saline + saline group.

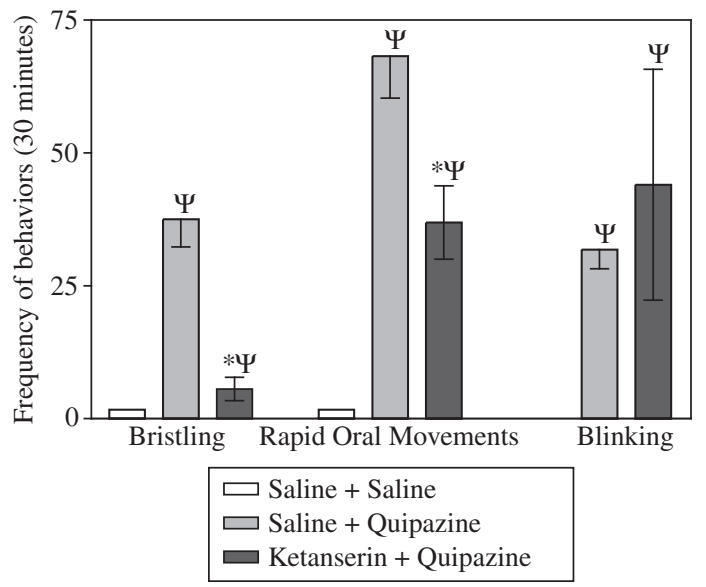

Figure 3. Frequency of behaviors associated to sleep-like reactions induced by $5-\mathrm{HT} 2 \mathrm{~A} / 2 \mathrm{C}$ agonist, quipazine and after 5-HT2A/2C antagonist, ketanserin treatment. Data are reported as mean \pm SEM. $* \mathrm{p}<0.05$ compared to saline + serotonin group. ${ }^{\psi} \mathrm{p}<0.05$ compared to saline + saline group. 
Table 1. Incidence of other patterns of behaviors observed during sleeping-like state induced by serotonin (5-HT) and quipazine and its associations with serotoninergic antagonists.

\begin{tabular}{lcccccc}
\hline \multicolumn{1}{c}{ Treatments } & Gaping & $\begin{array}{c}\text { Cloacal } \\
\text { movements }\end{array}$ & Hypomotility & $\begin{array}{c}\text { Pecking } \\
\text { Hypotony of } \\
\text { neck }\end{array}$ & $\begin{array}{c}\text { Closure of } \\
\text { eyes }\end{array}$ \\
\hline Saline + Saline & - & - & - & +++ & - & - \\
Saline + 5-HT & ++ & ++ & ++++ & + & - & +++++ \\
LY53857 + 5-HT & - & - & +++ & + & - & +++++ \\
Ketanserin + 5-HT & - & - & +++ & ++ & - & +++++ \\
Saline + Quipazine & +++++ & +++ & +++++ & - & ++ & ++++ \\
Ketanserin + uipazine & - & +++ & +++++ & + & - & ++++ \\
\hline
\end{tabular}

responses displayed by the birds was characterized by typical hypnogenic reactions of the gallinaceous (AyalaGuerrero et al., 2003; current paper). Episodes of sleepiness presented latency smaller than two min. Aspects of this sequence during natural sleep were described in turkeys in a distinguished paper (Ayala-Guerrero et al., 2003). However, these authors were concerned about electrophysiological analysis of sleep, not approaching the time course of behavioral and autonomic events.

Only one study has investigated the permeability of BBB to 5-HT in a gallinaceous genus (Hanig et al., 1970). In this work, parenteral injection with a high dose of 5-HT ( $\left.8 \mathrm{mg} . \mathrm{kg}^{-1}\right)$ caused an increase in its brainstem content in neonate chicks. Increased permeability of the BBB to 5-HT correlated with its conversion to 5-hydroxyindole acetic in the brainstem and roosting response. Roosting is a characteristic behavior, which is expressed during alternation between sleeping and wakening, however other behaviors were not reported.

In our study, previous administration of 5-HT2C antagonist, LY53857, reduced the frequency of the episodes of feather bristling and rapid oral movements, however it did not interfere with the response of blinking and closure of the eyes. In mammals, yawning is one of the stages when preparing for sleep (Daquin et al., 2001). This reaction possesses a serotoninergic component that was blocked by 5-HT2C antagonist in rats (Stancampiano et al., 1994; Protais et al., 1995; Argiolas and Melis, 1998; Beale and Murpree, 2000; Daquin et al., 2001). Rapid oral movements and gaping were observed in all the birds before the sleeping-like state similarly to yawning in mammals.

Quipazine-induced yawning-like behavior was completely blocked by 5-HT2A antagonist, ketanserin. Our observations are similar to those reported in cats (Trulson et al., 1982). These authors described a suppression of the quipazine-evoked gaping response after pretreatment with 5-HT2A antagonists, methysergide and cinnanserin.

Rapid oral movements were disclosed as expressions dependent on 5-HT2C and 5-HT2A receptors activation. In fact, such response represents a component associated to yawning-like behavior induced by 5-HT and quipazine. Rapid oral movements are accompanied by synchro- nized motor activity of the crop during the preparatory stage to sleep. These behaviors alternate with gaping, therefore, both are components of yawning. Rapid oral movements induced by 5-HT were nearly suppressed by LY53857, whereas those evoked by quipazine were just attenuated by ketanserin. In this respect, ketanserin couples preferably to 5-HT2A comparatively to 5-HT2C receptors must be considered (López-Giménez et al., 2001; Glennon et al., 2002).

Other behavioral reactions evoked by the 5-HT, e.g., feather bristling and blinking and closure of the eyes possibly do not request the activation of 5-HT2C receptors. In this context, an attempt to elucidate this uncertainty was undertaken. However, participation of 5-HT2A receptors was not successful because previous administration of ketanserin did not alter any of those responses induced by 5 -HT.

The long duration of the central action of the 5-HT can represent a difficulty in the transport and metabolic clearance of indoleamine in quails. Future investigations should examine this that question. Maybe in quails exist an inadequacy on the extraneuronal transport of increased brain concentration of 5-HT.

Recent evidence has shown an impairment of BBB function by 5-HT in anesthetized rats (Black, 1995; Winkler et al., 1995). In this condition, intravenous infusion of 5-HT decreased the electroencephalogram amplitude which was prevented by 5-HT2 antagonist cyproheptadine. This effect appears to be due to its ability to penetrate into the brain by inducing a short-term breakdown of the BBB, possibly via 5-HT2 receptors. In the present study, 5-HT2C antagonist administration reduced the frequency of some responses induced by parenteral route while treatment with antagonist 5-HT2A was ineffective. This may mean that these antagonists did not affect the permeability of BBB to 5-HT. Therefore, we postulated that 5-HT2C antagonist inhibited the effects of 5-HT by blocking the receptors located within the BBB.

In spite of the clear influence of the circulating 5-HT (after systemic administration) in the induction of a sleeping-like state in quails, its functional meaning remains to be elucidated. 
The aim of the present work was not to analyze the sleep patterns of quails nor to establish phylogenic correlation with the sleeping behavior of mammals. Therefore, future studies should investigate the physiological properties of the sleep of quails. In addition, studies will be necessary to elucidate the nature of serotoninergic actions concerning activation of autonomic and somatic mechanisms for initiation and stimulation of sleep in quails, e.g., feather bristling, blinking and closure of the eyes.

A general interpretation, which can be attained from our observations, is that 5-HT2C and 5-HT2A receptors in quails preserve homologous characteristics with that of mammals deduced from serotonin and quipazine blocked responses by LY53857 and ketanserin.

\section{References}

ARGIOLAS, A. and MELIS, MR., 1998. The neuropharmacology of yawning. Eur. J. Pharmacol., vol. 343, p. 1-16.

AYALA-GUERRERO, F., MEXICANO, G. and RAMOS, JJ., 2003. Sleep characteristics in the turkey Meleagris gallopavo. Physiol. Behav., vol. 78, p. 435-440.

BOADLE-BIBER, MC., 1993. Regulation of serotonin synthesis. Prog. Biophys. Molec. Biol., vol. 60, p. 1-15.

BEALE, M.D. and MURPHREE, T.M., 2000. Excessive yawning and SSRI therapy. Int. J. Neuropsychopharmacol., vol. 3, p. 275-276.

BLACK, KL., 1995. Biochemical opening of the blood-brain barrier. Adv. Drug Deliv. Rev., vol. 15, p. 37-52.

COOPER, JR., BLOOM, FE. and ROTH, RH., 1996. Serotonin (5-Hydroxytryptamine) and Histamine. In: Bloom FE. et al. (Eds.), The Biochemical basis of neuropharmacology, $7^{\text {th }}$ ed., New York University Press, p. 352-409.

DAQUIN, G. MICALLEF, J. and BLIN, O., 2001. Yawning. Sleep Med. Rev., vol. 5, p. 299-312.

GLENNON, RA., METWALLY, K., DUKAT, M., ISMAIEL, AM., DE LOS ANGELES J., HERNDON, J., TEITLER, M. and KHORANA, N., 2002. Ketanserin and spiperone as templates for novel serotonin 5-HT (2A) antagonists. Curr. Top. Med. Chem., vol. 2, p. 539-558.
HANIG, JP., AIELLO, E. and SEIFTER, J., 1970. Permeability of the blood-brain barrier to parenteral 5-hydroxytryptamine in the neonate chick. Eur. J. Pharmacol., vol. 12, p. 180-182.

LÓPEZ-GIMÉNEZ, JF., VILARÓ, MT., PALACIOS, JM. and MENGOD, G., 2001. Mapping of 5- $\mathrm{HT}_{2 \mathrm{~A}}$ receptors and their mRNA in monkey brain: $\left.{ }_{3} \mathrm{H}\right] \mathrm{MDL} 100,907$ autoradiography and in situ hybridization studies. J. Comp. Neurol., vol. 429, p. 571-589.

PROTAIS, P., WINDSOR, M., MOCAER, E. and COMOY, E., 1995. Post-synaptic 5-HT1A receptor involvement in yawning and penile erections induced by apomorphine, physostimine and mCPP. Psychopharmacology (Berl), vol. 120, p. 376-383.

REIS, LC., ALMEIDA, AC., CEDRAZ-MERCEZ, PL., OLIVARES, EL., MARINHO, Jr. A. and THOMAZ, CM., 2005. Evidence indicating participation of the serotonergic system in controlling feeding behavior in Coturnix japonica (Galliformes: Aves). Braz. J. Biol., vol. 65, p. 353-361.

STANCAMPIANO, R., MELIS, MR. and ARGIOLAS, A., 1994. Penile erection and yawning induced by 5-HT1C receptor agonists in male rats: relationship with dopaminergic and oxytocinergic transmission. Eur. J. Pharmacol., vol. 261, p. 149-155.

SCHMITT, A., MÖSSNER, R., GOSSMANN, A., FISCHER, IG., GORBOULEV, V., MURPHY, DL., KOEPSELL, H. and LESCH, KP., 2003. Organic cation transporter capable of transporting serotonin is up-regulated in serotonin transporter-deficient mice. J. Neurosci. Res., vol. 71, p. 701-709.

TRULSON, ME., BRANDSTETTER, JW., CRISP, T. and JACOBS, BL., 1982. Behavioral effects of quipazine in the cat. Eur. J. Pharmacol., vol. 78, p. 295-305.

TYCE, GM., 1990. Origin and metabolism of serotonin. $J$. Cardiovasc. Pharmacol., vol. 16, p. S1-S7.

WINKLER, T., SHARMA, HS., STALBERG, E., OLSSON, Y. and DEY, PK., 1995. Impairment of blood-brain barrier function by serotonin induces desynchronization of spontaneous cerebral cortical activity: Experimental observations in the anaesthetized rat. Neuroscience, vol. 68, p. 1097-1104

WU, X., KEKUDA, R., HUANG, W., FEI, YJ., LEIBACH, FH., CHEN, J., CONWAY, SJ. and GANAPATHY, V., 1998. Identity of the organic cation transporter OCT3 as the extraneuronal monoamine transporter (uptake 2) and evidence for the expression of the transporter in the brain. J. Biol. Chem., vol. 273, p. 32776-32786. 